\title{
A study on optimizing the characteristics of lithium-ion battery power source and operating cost for hybrid motorcycle
}

\author{
Nguyen Van Trang ${ }^{1}$, Nguyen Duy Tan ${ }^{2, *}$, Pham Tuan Anh ${ }^{3}$
}

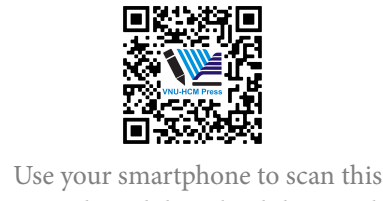

QR code and download this article
${ }^{1}$ Ho Chi Minh City University of Technology and Education

${ }^{2}$ Tran Dai Nghia University

${ }^{3}$ Nguyen Tat Thanh University

Correspondence

Nguyen Duy Tan, Tran Dai Nghia University

Email: duytan719@gmail.com

History

- Received: 23-9-2019

- Accepted: 31-12-2020

- Published: 28-2-2021

DOI : 10.32508/stdjet.v3iSI2.600

\section{Check for updates}

\section{Copyright}

(.) VNU-HCM Press. This is an openaccess article distributed under the terms of the Creative Commons Attribution 4.0 International license.

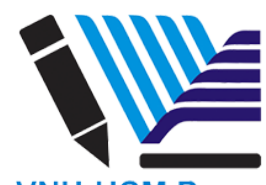

VNU-HCM Press

\begin{abstract}
This study presents a research related to a Plug-in Hybrid Electric Motorcycle (HEM) which renovated from a Honda Lead 110cc with rear wheel is driven by original internal combustion engine and continuously variable transmission, while front wheel is directly-driven by a 48V - 1,000W BLDC Hub-Motor. The research focuses on optimal calculating, designing, prototyping and testing an electric power supply using Lithium-ion (Li-ion) battery pack to replace the lead-acid battery. The simulation and experimental results are able to evaluate the dynamic characteristics and operating cost of HEM. The study has been designed and prototyed a $48 \mathrm{~V}-33 \mathrm{Ah} \mathrm{Li-ion} \mathrm{battery} \mathrm{pack} \mathrm{with}$ a Battery Management System (BMS) circuit embeded on the vehicle. The battery pack is 10.84 (kg) weight and $8.11(\mathrm{I})$ volume, reduced $30(\mathrm{~kg})$ and 12.89 liters compared to the lead-acid battery where battery life is greater than 2,000 cycles.

In only electric motor mode, the longest distance of the HEM is $78.77(\mathrm{~km})$ for a half load, only driver, and $65.83(\mathrm{~km})$ for full load, one driver, and one passenger. Maximum speed is $52.67(\mathrm{~km} / \mathrm{h})$ for a half load and $48.42(\mathrm{~km} / \mathrm{h})$ for full load. In hybrid mode until SOC reduce to 50\%, HEM can travel $64.366(\mathrm{~km})$ for a half load and $54.477(\mathrm{~km})$ for full load. The fuel consumption in the each case is 2.162 and $2.425(\mathrm{l} / 100 \mathrm{~km}), 0.5$ liter lower than the original one and 0.3 liter lower than lead-acid battery. The cost of investment in HEM is 56 million VND and the operating cost is 1,106 VND/km, while the original vehicles are 40 million VND and 1,352 (VND/km). For every $1 \mathrm{~km}$ using hybrid vehicles, $246.88 \mathrm{VND}$ will be saved, after about 3.1 years, it will recoup the spending on investment. At the end of the motorcycle life cycle is about 200,000 km, and 43 million VND will be saved.

Key words: Lithium-ion battery, hybrid electric motorcycle, hybrid vehicle, battery management system (BMS)
\end{abstract}

\section{INTRODUCTION}

Currently, people on the world is facing increasingly exhausted fossil fuel sources and global climate change, the urgent requirement is to reduce greenhouse gas emissions and use energy resources effectively ${ }^{1-3}$. In the previous studies, the authors presented the current situation of the number and growth trend of motorcycles in Ho Chi Minh City ${ }^{4-6}$ as well as the impact of motorcycles using internal combustion engines on environmental pollution and its fuel economy ${ }^{7-10}$. From there, the authors proposed a plan to renovate the $110 \mathrm{cc}$ Honda Lead into a gasoline-electric hybrid motorcycle. The main issues have been solved such as: Selecting a general layout schematic; choose electric motors, generators, batteries; propose principles and operating mechanisms of the power management system ${ }^{11}$; Modeling and simulating the operation of vehicles after renovation with Matlab/Simulink software ${ }^{12}$; Researching overview of Lithium-ion battery and its applicability on hybrid motorbikes, proposing a design solution for
Lithium-ion battery pack for renovated hybrid electric motorcycles ${ }^{13}$.

In this study, the authors continue to solve the following outstanding issues: Manufacturing and testing of Li-ion battery pack; Model the Li-ion battery pack and simulate vehicle operating modes when installing the Li-ion battery pack; Assessing the dynamic characteristics of the vehicle and optimizing the operating characteristics of the battery pack; Calculate the cost of renovation and operating of the vehicle. Raise issues that need further study to conduct wide-ranging application.

\section{PROBLEM IDENTIFICATION AND METHODOLOGY}

The prototype of Lithium-ion battery pack must be conducted to test some specifications susch as funtion of battery management system, SOC, etc.

\section{Pair the Li-ion cells into a battery pack}

In previous study ${ }^{13}$, authors calculated and proposed a plan to design a Li-ion battery pack that is paired 
from $180 \mathrm{Li}$-ion cells type SANYO UR18650F-SCUD$3^{14}$ to get a $48 \mathrm{~V}-33 \mathrm{Ah}$ battery pack. As seen in Figure 1,180 cells are paired into 12 serial blocks, each block consists of 15 cells in parallel.

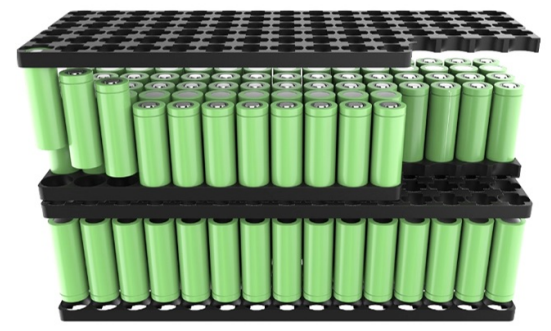

Figure 1: Paired cells into a battery pack

This option gives the advantage of good cell selfbalance $^{15}$, simple pairing, just need to use only one BMS 48V-33Ah circuit for the battery pack. The downside is the battery pack connected to one unit, so it is difficult to disperse to take advantage of the vehicle free space. After pairing (excluding the box), the battery pack weighs $8.64 \mathrm{~kg}$ and has dimensions (L $\mathrm{x} \mathrm{W} \times \mathrm{H})=240 \mathrm{~mm} \times 200 \mathrm{~mm} \times 136 \mathrm{~mm}$. The volume is 6,528 (1). This volume accounted for $17.6 \%$ of the vehicle's U-Box, meeting the size requirements

\section{Prototype BMS, Battery Management Sys-} tem

The requirements and features have to be achieved of battery pack mentioned in the previous study ${ }^{13}$. In Figure 2, the authors designed and manufactured a BMS 48V-33Ah circuit for the battery pack consists of following blocks:

- Cells-balancing and multiplexer voltage signal block;

- Regulator and power supply block

- Central control unit;

- Communication block

- Protection block such as: overcurrent, overvoltage and overheat, short circuit...

Cells balancing block is using 2 cell-balancing control ICs LTC3300 from Linear Technology. Each IC receives signal and controls 6 serial nodes. 12 cell voltage sensor to get signal and 12 executive structure to balance cell.

Central control unit is using a programmable MCU to control charge-discharge cycles, read-write battery logs and communicate with external interface... In this circuit, authors have chosen MCU PIC18F47J53.
Regulator and power supply block, 3.3V power is supplied by a regulating IC named LT1761ES5-3.3.

Communication block: BMS circuit communicate with external interface by USSB protocol through a transceiver LTM2884CY.

Charge-discharge controller and protection block: To monitor charge-discharge current and voltage, authors used a pair of LTC 6804 and LTC 6802.

Power amplifier block: to control cell balancing, consist of 12 MOSFET RQJ3003PGDQALT, rate voltage is $30 \mathrm{~V}$, rate current is $3 \mathrm{~A}$. Added an RC type Low-pass filter to filter the cell voltage signal.

In addition, to ensure operational and safety features, BMS circuit is included other auxiliary components such as: current sensors, self-healing fuse, power filters, and temperature sensor in Figure 3.

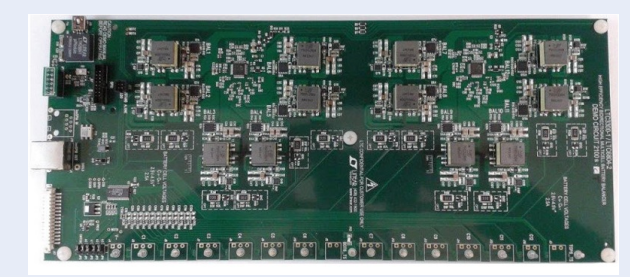

Figure 3: Completed BMS circuit

Connection of the BMS circuit to battery pack and solder power connector, communication jack and battery capacity level indicators. Then pack the battery pack with electrical insulation papers. Choose a plastic toolbox that fits a laptop size, fits the battery pack, and reprocess the case. Because the battery pack and BMS circuitry need heat dissipation, the cover is made of aluminum, thickness $3 \mathrm{~mm}$, screwed in holes, hand-held holes and milling the power connector plug holes. Then insert the battery pack into the box. Completed battery pack has a weight of $10.84 \mathrm{~kg}$ and dimensions of $308 \times 183 \times 144 \mathrm{~mm}$ ( $\mathrm{L} \times \mathrm{W} \times \mathrm{H})$, volume of 8.11 liters accounted for $21.9 \%$ of the $\mathrm{U}$ Box that illustrated in Figure 4.

\section{Testing battery pack}

The power source of $\mathrm{DC} 60 \mathrm{~V}-40 \mathrm{~A}$ can be used to adjust the power supply, an adjustable Tungsten resistor set to create the load. Testing to figure out charge-discharge characteristics, cell balancing, lifetime cycle, temperature rising test with high current. Because the experimental conditions could not keep the room temperature fixed at $25^{\circ} \mathrm{C}$, authors chose a closed room and adjust the air conditioner at $25^{\circ} \mathrm{C}$ for testing. 


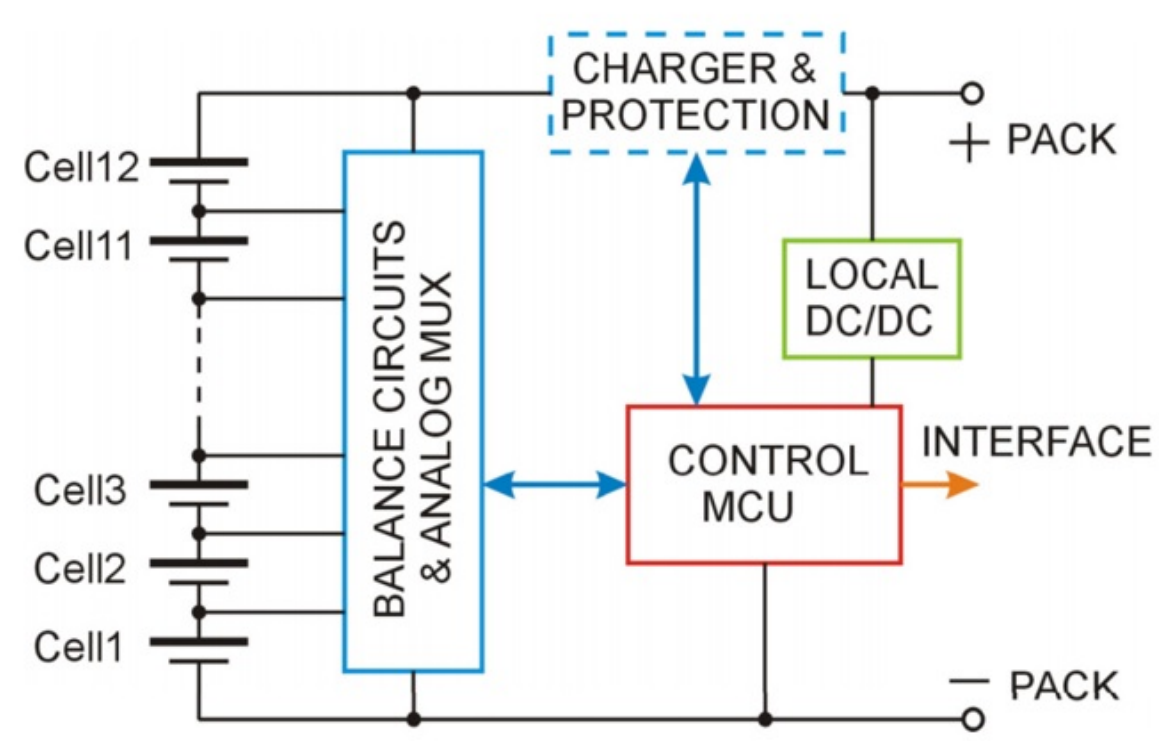

Figure 2: BMS circuit block diagram

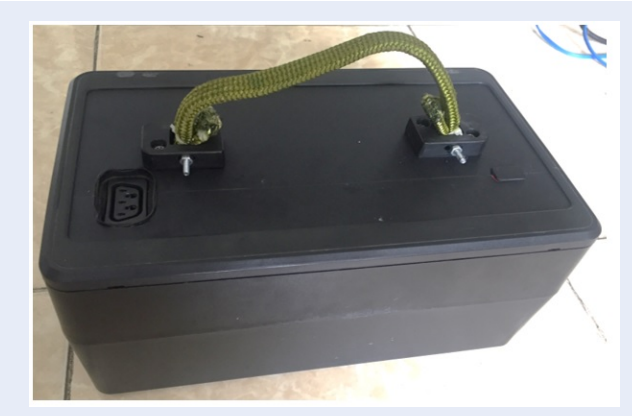

Figure 4: Completed battery pack

The results include:

- Cell over-voltage protection at $4.25 \pm 0.025 \mathrm{~V}$.

- Balance the cell automatically in two states of charge and discharge with the maximum difference of $0.03 \mathrm{~V}$. Charge the battery pack in CC-CV method (Constant Current - Constant Voltage) constant current $\mathrm{I}_{n}$ $=21 \mathrm{~A}$, constant voltage $\mathrm{U}_{n}=50.4 \mathrm{~V}$, stop when $\mathrm{I}_{n}$ $\leq 1.5 \mathrm{~A}$, room temperature at $25^{\circ} \mathrm{C}$. As seen in Figure 5 , battery pack capacity reaches $98-99 \%$ in about 2 hours. Then discharge in $\mathrm{C}_{1}$ mode $\left(\mathrm{I}_{p}=33 \mathrm{~A}\right)$ and stop discharge when SOC $=20 \%$, repeat in $500 \mathrm{cy}$ cles, battery pack capacity falls down to $23 \mathrm{Ah}(69.7 \%$ original capacity). This result is not much different when compared with the cell charge-discharge test mentioned in the previous study. So we can conclude, if the discharge with mode $\mathrm{C}_{5}$ or $\mathrm{C}_{10}$, and stop discharge at $\mathrm{SOC}=50 \%$, the longevity of the battery pack can reach over 2000 cycles while the capacity still over $60 \%$ original capacity.

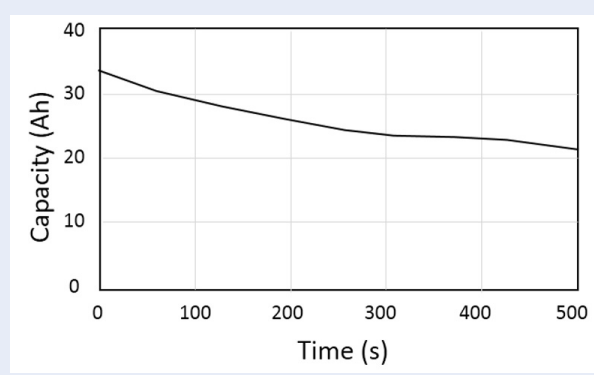

Figure 5: Battery pack lifetime characteristics

\section{BATTERY PACK MODELING AND SIMULATION OF OPERATING MODES IN MATLAB/SIMULINK}

\section{Li-ion battery pack modeling}

In the study ${ }^{12}$, authors modeled HEM assemblies and systems including:

- Modeling the gasoline engine and power train systems;

- Modeling the driver;

- Modeling electric motors 
- Modeling the vehicle dynamics

In this study, authors model Li-ion battery pack to predict the state of charge level (SOC), capacity, voltage and current when testing.

For designing battery pack and doing simulating of vehicle performance, the SOC is calculated from the following current integration:

$$
\begin{gathered}
S O C(t)=S_{O C}-\frac{1}{3600} \int_{t_{0}}^{t} \frac{I(\tau) \eta_{b a t}}{Q_{i}} d \tau \\
\operatorname{SOC}\left(t_{0}\right)=\operatorname{SOC}_{0} ;
\end{gathered}
$$

Where $\mathrm{Q}_{i}$ is battery pack capacity $(\mathrm{Ah})$

The relationship between terminal voltage and current can be expressed following equation:

$$
U_{H V}=U_{O C}-U_{r}
$$

Where $\mathrm{U}_{r}$ is dropped voltage caused by internal resistance of battery pack

$$
U_{r}=I . R
$$

Where $\mathrm{R}$ is internal resistance of battery

\section{Modeling controller}

Rule-based algorithms are used to control the power management system of the HEM. There are two important rules in this controller:

- Internal combustion engine has to operate in optimal performance area;

- The battery pack has to be optimized SOC, SOC is kept in:

$$
S O C_{\min } \leq S O C \leq S O C_{\max }
$$

Controller has three input signals: Demand power of driver; state of charge of battery pack; actual speed of HEM. Two output elements are demand power of gasoline engine and demand power of electric motor.

\section{Simulating HEM operation}

To evaluate dynamic characteristics and fuel consumption of HEM when mounted Li-ion battery pack. Models of parts in system are concreted to blocks in Matlab/Simulink as shown in Fig 6. Then simulated HEM under some motorcycle basic testing cycles such as: Japan 10-15 Mode, WVUCITY, FTP75, ECE-R15.

\section{SIMULATION RESULTS AND DISCUSSION}

In order to compare the results of HEM using leadacid battery with previous study ${ }^{10-12}$. In this paper, authors focused on the results of HEM simulation under the Japan 10-15 Mode cycle from $t=0$ with the step increase time of 0.1 to the end of the cycle $(660$ seconds) and then repeat until SOC $=50 \%$. The typical simulation results are shown as in Figure 7.

In simulation cycle, the HEM's response speed is very close to the required speed of the cycle, at the points that speed changes suddenly, the vehicle's speed is still late or overshoot, but the level of deviation is less than $0.5 \%$, better than the deviation when the HEM mounted lead - acid battery is $\sim 2 \%$. The reason may be the weight of the power supply unit was reduced and reduces the vehicle's weight $30 \mathrm{~kg}$, leading to a decrease in HEM's inertia.

As seen in Figure 8, when the required power $\left(\mathrm{P}_{k \_ \text {demand }}\right)$ stays in the optimal efficiency area of internal combustion engine, the internal combustion engine will drive rear wheel, the electric motor will be turned off. In case $\mathrm{P}_{k \_ \text {demand }}$ smaller than the minimum limited point of high efficiency zone, the electric motor will drive front wheel, the gasoline engine will be turned off. In case $\mathrm{P}_{k \_ \text {demand }}$ higher than the maximum limited point of efficiency zone, both engines work together, electric motor supplies power to bring internal combustion engine work in the optimal area. In simulation cycle, total consumed electrical energy accounts for $32 \%$ of total vehicle demand energy. The remaining energy (68\%) is provided by gasoline engine. Electrical energy is equivalent to $48.15 \%$ of the energy from gasoline engines as shown in Figures 9 and 10 and Figure 11.

Fuel consumption of HEM is $2.162(1 / 100 \mathrm{~km})$ foe a half load, and $2.425(1 / 100 \mathrm{~km})$ for full load. Estimated range until SOC reduced to $50 \%$ is $64.36 \mathrm{~km}$ for a half load and $54.47 \mathrm{~km}$ for full load given in Table 1.

\section{Renovating cost}

The investment on buying and renovating include:

- Cost of buying new scooter: $\$ 1,709$

- Battery pack: $\$ 414$

- Other supplies and costs: $\$ 275.2$

Details shown in Table 2.

\section{Operating cost}

In order to calculate the operating costs of base scooter and renovated HEM, authors choose the calculation method and conversion all of depreciation and basic operating costs per 1 kilometer. 


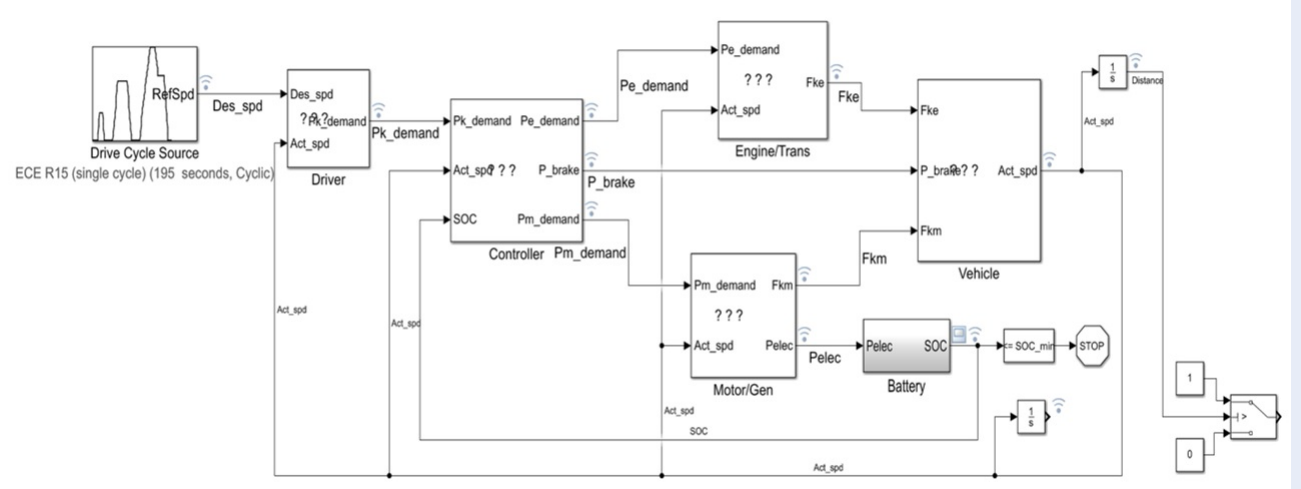

Figure 6: HEM block diagram in Matlab/Simulink

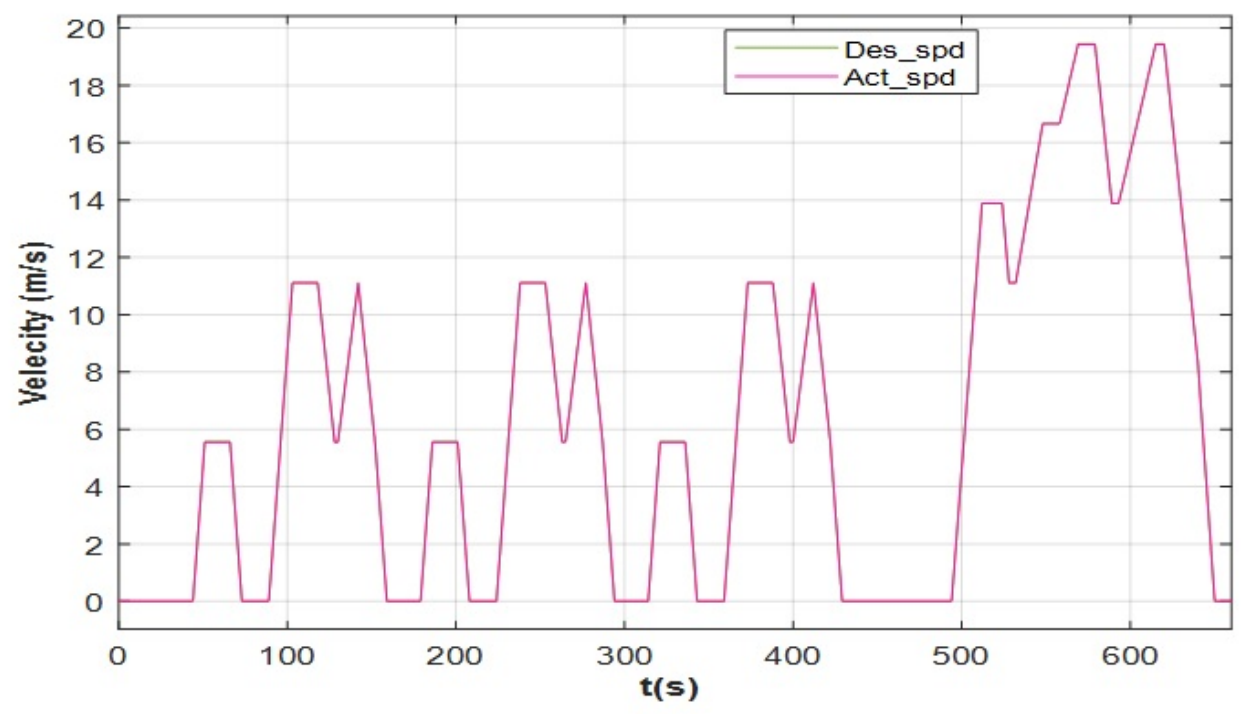

Figure 7: Velocity response

According to H. D. Tung's research ${ }^{16}$, motorbike life depends on many factors such as production quality, environment, usage terrain, maintenanc, and usage habits. But on average, motorcycles in Vietnam have a life expectancy of about $200,000 \mathrm{~km}$ with two major repairs at $100,000 \mathrm{~km}$ and at $150,000 \mathrm{~km}$.

Based on the simulation results in section 4 , when operating in hybrid mode with Japan 10-15 Mode cycle, the generated power by the electric motor around $48.15 \%$ of the total HEM demand power. To calculate the operating cost, authors accept the assumption that all the details of the internal combustion engine and powertrain of the HEM have a lower operating frequency than the original vehicle and all services of the vehicle are also extended by $48.15 \%$. Thus, the life of the HEM is about $296,300 \mathrm{~km}$.

- Depreciation of base scooter: $40,000,000 \mathrm{VND} / 200,000 \mathrm{~km}=200(\mathrm{VND} / \mathrm{km})$

- Depreciation of renovated supplies: 6,439,000 $\mathrm{VND} / 296,300 \mathrm{~km}=21.73(\mathrm{VND} / \mathrm{km})$

- Depreciation of base scooter in hybrid mode: $40,000,000 \mathrm{VND} / 296,300 \mathrm{~km}=135(\mathrm{VND} / \mathrm{km})$

In half-load mode, HEM consumed $2.162(1 / 100 \mathrm{~km})$, the original one consumed $2.693(1 / 100 \mathrm{~km})$ while in full-load mode are 2.425 and $3.012(1 / 100 \mathrm{~km})$. In particular, used ratio of motorcycles in HCM city is $1.25^{16}$. There will be 1 motorcycle to carry 2 people. From there, we calculate the average consumption of HEM and original vehicle:

- Average fuel consumption of original vehicle: 


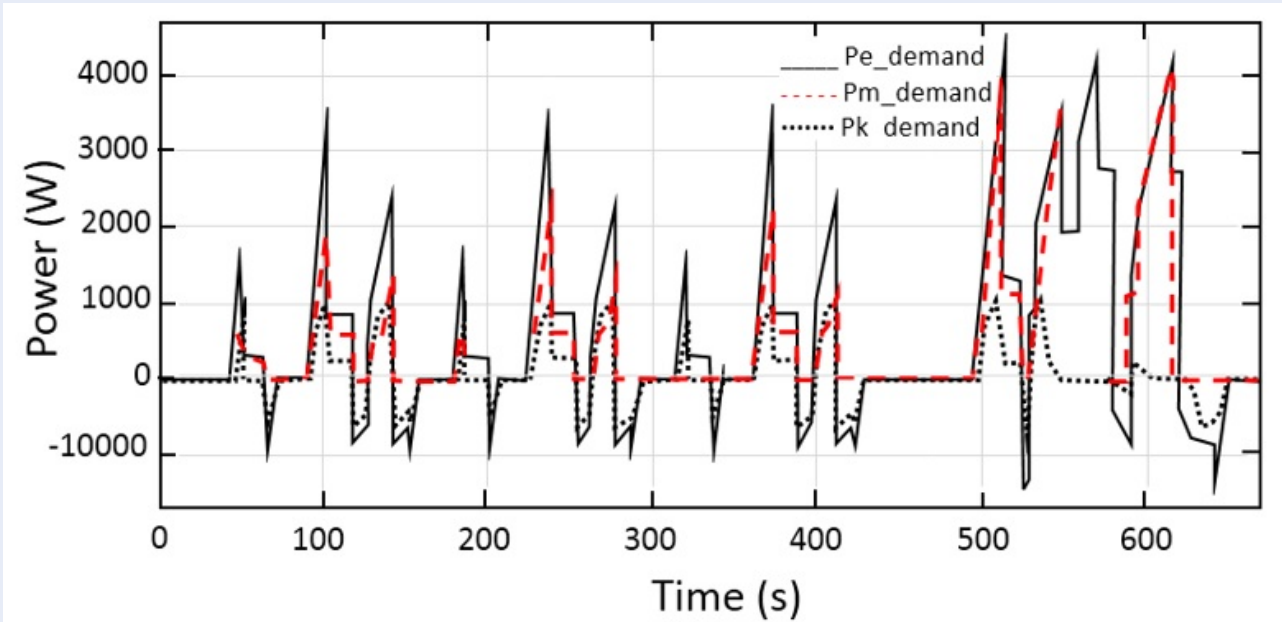

Figure 8: Demand power distribution

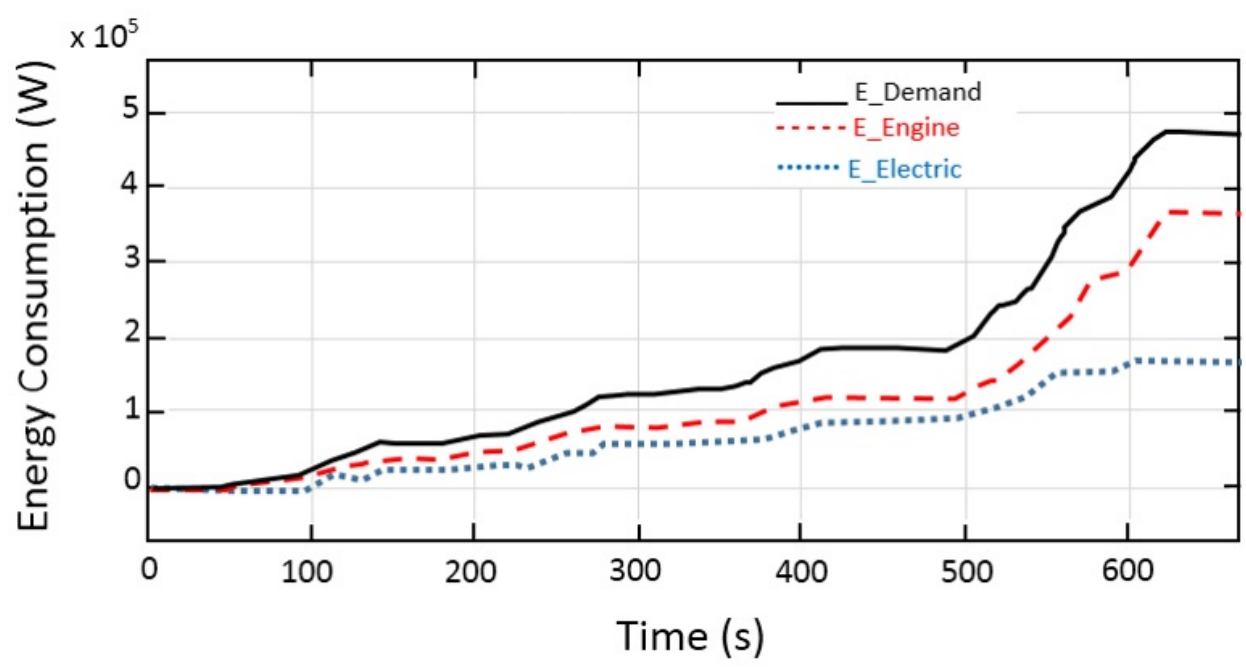

Figure 9: Energy distribution ratio

$(2.693 \times 3+3.012) / 4=2.77(1 / 100 \mathrm{~km})$

- Average fuel consumption of HEM:

$(2.162 \times 3+2.425) / 4=2.228(1 / 100 \mathrm{~km})$

- MogasA95 price in HCM City in Jun/2019: 20,000 (VND/l)

- Fuel cost of original vehicle: $2.77 \times 20,000 / 100=$ $554.55(\mathrm{VND} / \mathrm{km})$

- Fuel cost of HEM: 2.228 x 20,000/100 $=445.55$ $(\mathrm{VND} / \mathrm{km})$

With the operation cycle stopped discharging at SOC $=50 \%$, according to the characteristics of Li-ion cell and the Li-ion battery pack mentioned in section 2, the battery life is greater than 2,000 cycles while ensuring the battery capacity does not fall below $50 \%$. Each cycle of charging and discharging 50\% capacity, the HEM get $64.336 \mathrm{~km}$, we calculate the battery life is $128,672 \mathrm{~km}$.

Depreciation of battery pack:

9,687,000/128,672 = 75.284 $(\mathrm{VND} / \mathrm{km})$

Power of battery pack: $12 \mathrm{~V}$ x $33 \mathrm{Ah}=1584 \mathrm{Wh}$

Each charge cycle of $50 \%$ of power consumption consumes $0.792 \mathrm{kWh}$ with an estimated electricity price of $2,000(\mathrm{VND} / \mathrm{kWh})$

The cost of electricity: $0.792 \times 2,000 / 64.336=24.62$ $\mathrm{VND} / \mathrm{km}$. According to the Honda Lead $110 \mathrm{cc}$ oper- 


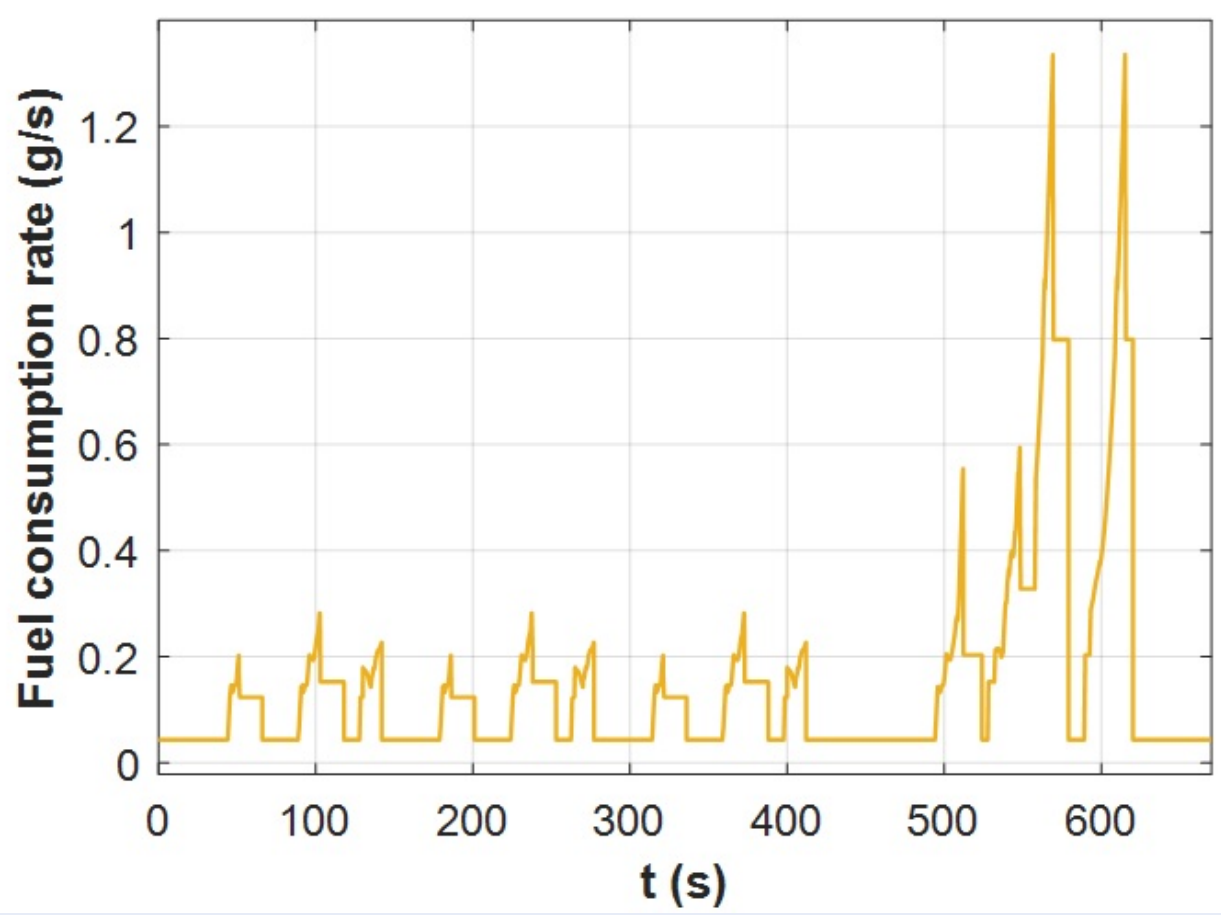

Figure 10: Fuel consumption rate

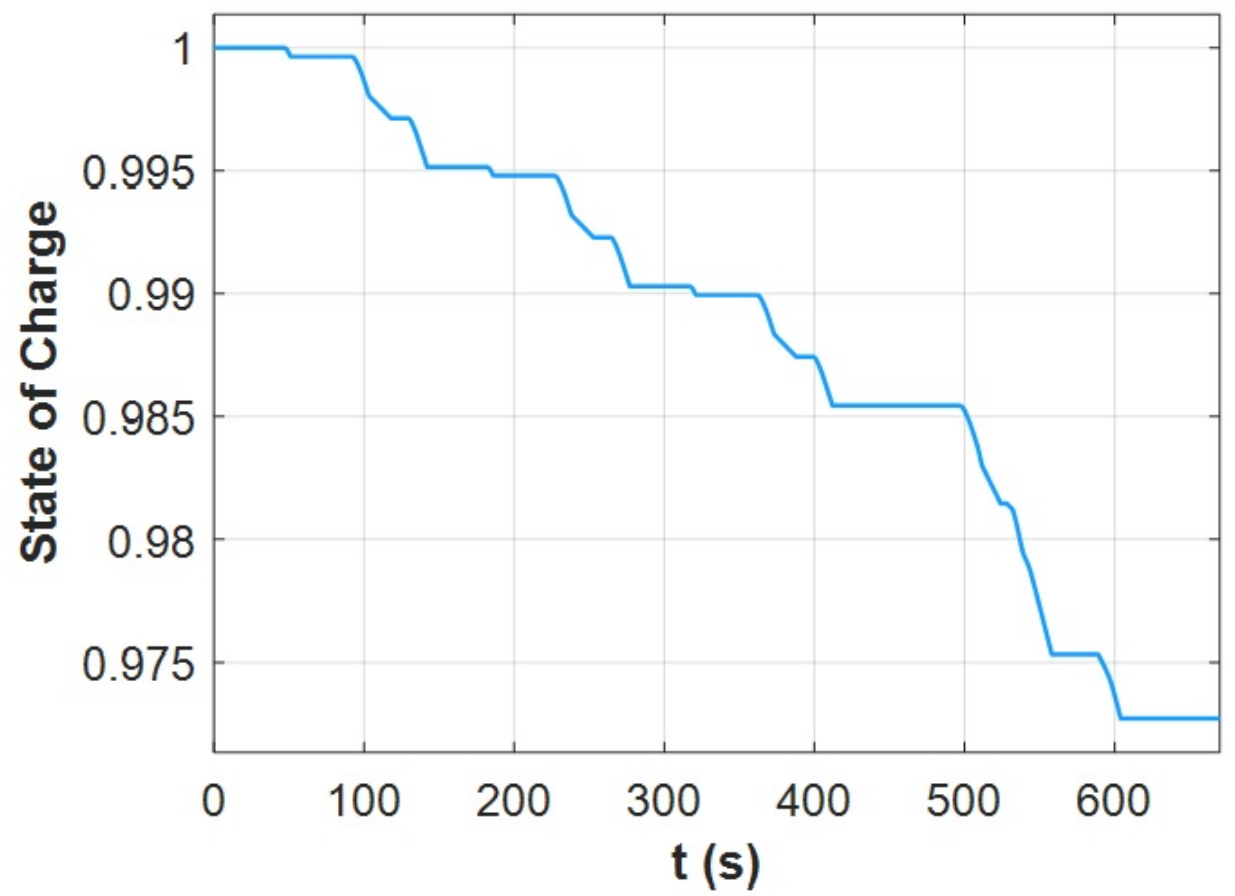

Figure 11: State of charge (SOC) vs. time 


\begin{tabular}{|c|c|c|c|c|}
\hline \multirow[t]{2}{*}{ Characteristics } & \multicolumn{2}{|c|}{ Lead-acid battery HEM } & \multicolumn{2}{|c|}{ Li-ion battery HEM } \\
\hline & Half load & Full load & Half load & Full load \\
\hline Fuel consumption (1/100km) & 2.521 & 2.866 & 2.162 & 2.425 \\
\hline $\begin{array}{l}\text { Estimated range in hybrid mode until SOC re- } \\
\text { duced to } 50 \%(\mathrm{~km})\end{array}$ & 43.43 & 36.48 & 64.36 & 54.47 \\
\hline Estimated range in electric mode (km) & 47.6 & 42.4 & 78.77 & 65.83 \\
\hline Maximum speed in electric mode $(\mathrm{km} / \mathrm{h})$ & 44.75 & 41.3 & 52.67 & 48.42 \\
\hline Maximum slope in electric mode (\%) & 3.54 & 2.39 & 4 & 2.54 \\
\hline Renovated HEM weight $(\mathrm{kg})$ & 238 & 303 & 208 & 273 \\
\hline Battery pack weight (kg) & \multicolumn{2}{|c|}{41.6} & \multicolumn{2}{|c|}{10.84} \\
\hline Battery pack volume (l) & \multicolumn{2}{|c|}{14.5} & \multicolumn{2}{|c|}{6.53} \\
\hline Battery pack volume including box (l) & \multicolumn{2}{|c|}{21} & \multicolumn{2}{|c|}{8.11} \\
\hline
\end{tabular}

\begin{tabular}{lllll}
\multicolumn{2}{l}{ Table 2: The cost for renovating to hem } \\
\hline Contents & Quantity & Unit price (\$) & Amount (\$) & Amount (x1,000 VNĐ) \\
\hline New Honda Lead scooter & 1 & 1,709 & 1,709 & 40,000 \\
BLDC motor 48V-1000W & 1 & 117 & 117 & $2,737.8$ \\
BLDC controller & 1 & 24 & 24 & 561.6 \\
Handle with Hall sensor & 1 & 8.2 & 8.2 & 191.88 \\
Li-ion cell 18650 & 180 & 2.3 & 414 & $9,687.6$ \\
Battery management system & 1 & 14 & 14 & 327.6 \\
Power management system & 1 & 12 & 12 & 280.8 \\
Machining and assembling & 1 & 100 & 100 & 2,340 \\
Total & & & $2,398.2$ & $56,127.28$ \\
\hline
\end{tabular}

Exchange rate: $23,400 \mathrm{VN} 円 / \$$

ation and maintenance manual ${ }^{17}$, stipulating the cycle of maintenance, repair and longevity of some spare parts of natural wear and tear of the vehicle. Combination with the quotation of services and spare parts supplies of Honda Vietnam's authorized dealer in Ho Chi Minh City, we calculate other cost and depreciation.

\section{Evaluation of renovating and operating cost}

According to the calculation results above, we set up a table to calculate the cost, figure out the break-point when renovating and operating vehicles given in Table 3.

The initial investment of the renovated HEM is nearly VND 16 million higher than the original vehicle. However, in the operating life, every $1 \mathrm{~km}$ of opera- tion, 246.88 VND will be saved by the HEM. Breakpoint when investing in renovating and operating HEM with Li-ion battery pack is about $26,000 \mathrm{~km}$.

According to the research results of Mr. Tung ${ }^{16}$ too, the average distance traveled by motorbike of people in Ho Chi Minh City is $23 \mathrm{~km}$ per day, equivalent to $8,395 \mathrm{~km} /$ year. Thus, if investing in renovation of Honda Lead to a HEM, after about 3.1 years, it will recoup the spending on investment.

After 3.1 years, for every additional $1 \mathrm{~km}$ of operation, 246.88 VND will be saved. So by the end of life of the original vehicle $(200,000 \mathrm{~km})$, equivalent to 23.8 years, 43 million VND will be saved by the HEM, equivalent to the money to buy a new motorcycle as in Figure 12. In Ho Chi Minh City with about 8.6 million motorcycles, if investing to renovate traditional gasoline motorbikes into HEM, it will cost 137,600 billion VND, 


\begin{tabular}{|c|c|c|c|c|c|c|}
\hline \multirow[t]{2}{*}{ Contents } & \multicolumn{2}{|c|}{ Investment (x 1,000VND) } & \multicolumn{2}{|c|}{ Distance $(\mathrm{km})$} & \multicolumn{2}{|c|}{ Cost (VND/km) } \\
\hline & $\begin{array}{l}\text { Original } \\
\text { scooter }\end{array}$ & HEM & $\begin{array}{l}\text { Original } \\
\text { scooter }\end{array}$ & HEM & $\begin{array}{l}\text { Original } \\
\text { scooter }\end{array}$ & HEM \\
\hline Depreciation of original vehicle & 40,000 & 40,000 & 200,000 & 296,300 & 200 & 135 \\
\hline Depreciation of renovating & 0 & 6,439 & 0 & 296,300 & 0 & 21.73 \\
\hline Fuel & 55.455 & 44.55 & 100 & 100 & 554.55 & 445.55 \\
\hline Electricity & 0 & 1.584 & 0 & 64.336 & 0 & 24.62 \\
\hline Li-ion battery & 0 & 9,687 & 0 & 128,672 & 0 & 75.28 \\
\hline Lead-acid battery & 450 & 450 & 30,000 & 44,445 & 15 & 10.125 \\
\hline The $1^{\text {st }}$ maintenance & 600 & 600 & 2,000 & 2,963 & 300 & 202.5 \\
\hline The $2^{\text {nd }}$ maintenance & 1,100 & 1,100 & 5,000 & $7,407.5$ & 220 & 148.5 \\
\hline The $1^{s t}$ major repair & 3,000 & 3,000 & 100,000 & 148,150 & 30 & 20.25 \\
\hline The $2^{\text {nd }}$ major repair & 5,000 & 5,000 & 150,000 & 222,225 & 33.33 & 22.5 \\
\hline Total & & & & & 1,353 & 1,106 \\
\hline
\end{tabular}

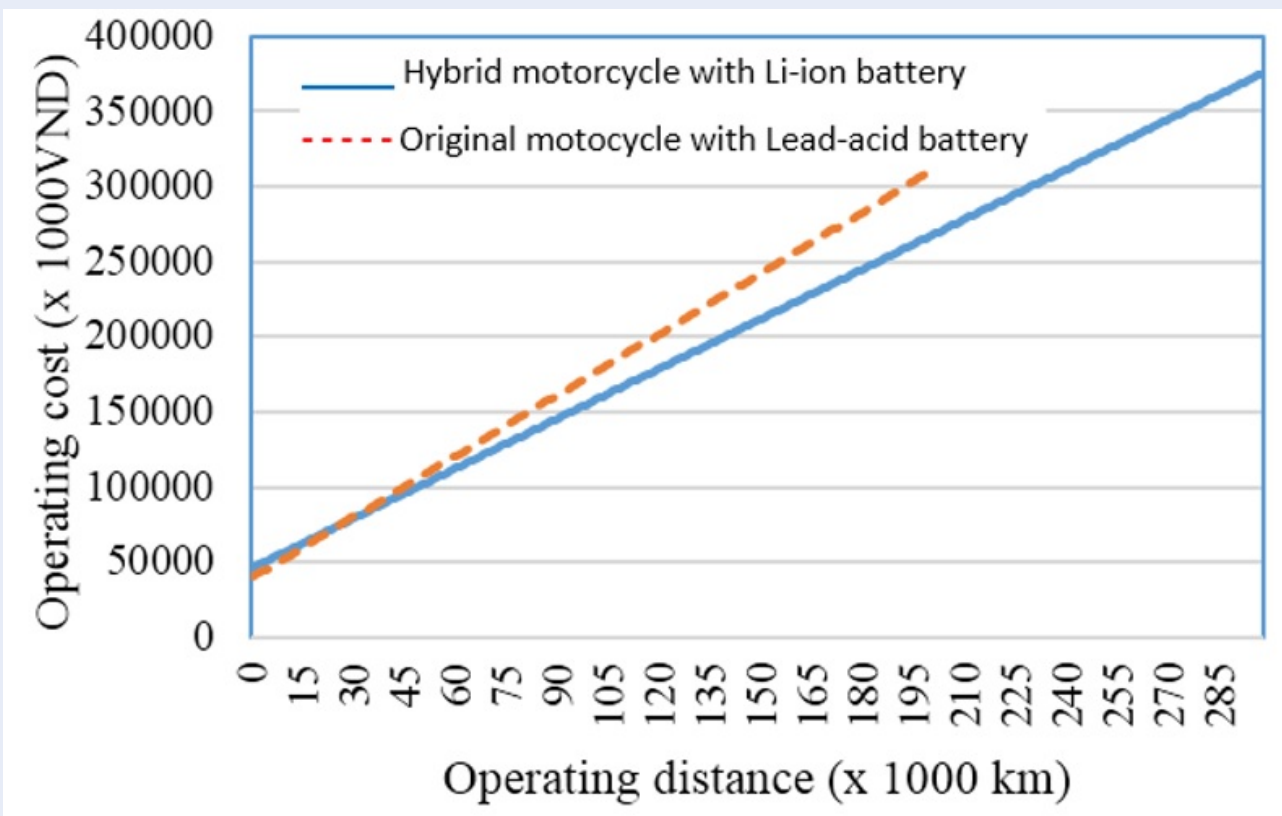

Figure 12: Operating cost of HEM and original vehicle 
but after 23.8 years, the operating cost will be reduced by 369,800 billion VND, the saved amount is 232,200 billion VND. If compared to the cost of Ho Chi Minh City - Long Thanh - Dau Giay express way is 375 billion $\mathrm{VND} / \mathrm{km}(20,630$ billion in total for $55 \mathrm{~km})$, this amount can build transport infrastructure equivalent to about $600 \mathrm{~km}$ of express way. At the same time, the demand for A95 gasoline will decrease by nearly 9.4 million $\mathrm{m}^{3}$. Compared with the country's gasoline consumption in the first 6 months of 2018, it was 4.43 million $\mathrm{m}^{318}$. The amount of gasoline saved is enough to supply gasoline for the whole country in about 1 year.

Thus, the renovating motorbikes using internal combustion engines with gasoline fuel into HEM has been achieved the expectations in terms of reducing fuel consumption to ensure energy security while reducing emitting $50 \%$ of $\mathrm{CO}$ and $\mathrm{HC}$ into the environment $^{19}$.

\section{CONCLUSIONS}

In this study, the calculation and experiment have been conducted to:

- Analyze advantages and disadvantages of energy storage systems used in hybrid vehicles, design, prototype, and testing for the $48 \mathrm{~V}$ - 33Ah Li-ion battery pack and BMS circuit to meet the requirements of dynamic characteristics and appropriate operating conditions of the vehicle.

- Calculate, test the HEM in many operation modes, and simulate HEM in Matlab/Simulink, the evaluation of the dynamic characteristics and fuel economy of the renovated HEM have been compared to original vehicles.

- Calculate the cost of investing, renovating and operating of renovated HEM, compare to the original vehicle, and give assessments.

\section{ACKNOWLEDGMENT}

This study was supported by Ho Chi Minh city University of Technology and Education, Electrical Measurement Laboratory at Tran Dai Nghia University.

\section{CONFLICT OF INTEREST}

The authors hereby guarantee that there is no conflict of interest in the publication of the article.

\section{AUTHORS' CONTRIBUTION}

Nguyen Van Trang: analysis and interpretation of results; approved the final version of the manuscript. Nguyen Duy Tan: draft manuscript preparation; data collection.

Pham Tuan Anh: study conception; correction of the draft manuscript.

\section{REFERENCES}

1. Ga BV, Nam TV, Tung TTH. Energy - Environment Issue in Transport of Vietnam. The 4th Seminar on Environment Science and Technology Issues Related to the Sustainable Development for Urban and Coastal Areas. Japan Vietnam Core University Program. Danang. 2007;p. 264-269.

2. Chi PM. World oil and gas industry in 2015. Petroleum Journal. Institute of Economic and Management, Hanoi Polytechnic University. 2016;11(2).

3. Syahri S, Resosudarmo BP, Tomo HS. Study on Air Quality in Jakarta, Indonesia - Future Trends, Health Impacts, Economic value and PolicyOptions. Asian Development Bank. Metro Manila Philippines. 2002;.

4. Report of vehicle growth statistics 2011-2015. Ho Chi Minh city Department of Transportation. 2016;

5. Phong NT. The report answers questions about construction planning, architecture and urban infrastructure in $\mathrm{Ho} C h \mathrm{i}$ Minh City," 13th section, Standing Committee of the National Assembly XIV. 2017;

6. Chung PH. The scheme to increase public passenger transport combined controlling personal vehicles in Ho Chi Minh city," Institute of Transportation Strategy and Development, MOT. 2019;.

7. Silva C, Ross M, Farias T. Evaluation of energy consumption, emissions and cost of plug-in hybrid vehicles. Energy Convers Manag. 2009;50(7):1635-1643. Available from: https: //doi.org/10.1016/j.enconman.2009.03.036.

8. Chau PT, Kameda T, Toriba A, Hayakawa K. Polycyclic aromatic hydrocarbons and nitropolycyclic aromatic hydrocarbons in particulates emitted by motorcycles. Kanazawa University, Japan. 2013;183:175-183. PMID: 23399401. Available from: https://doi.org/10.1016/j.envpol.2013.01.003.

9. Integrated Teaching and Learning Program. Transportation and the Environment. College of Engineering, University of Colorado Boulder. 2017;

10. Halter D. Sources of CO and NOx emissions research. 24th Com U.S. Environmental Protection Agency. 2017;

11. Anh PT, Tri DQ, et al. A study on Integration of Hybrid Technology to Honda Lead 110cc Motorcycle. National scientific and technological conference on mechanics-dynamics, Hanoi. 2016;.

12. Thịnh H, Trạng NV, Anh PT. Modelling and simulation of Hybrid Honda Lead 110cc Motorcycle with Front Wheel Electric Motor. National scientific and technological conference on mechanics-dynamics, Hanoi. 2016;.

13. Trang NV, Anh PT, Tan ND. Study on the optimal operating characteristics for lithium-ion batteries used in hybrid electric motorcycle," Science and Technology Development Journal. 2017;20(K6):51-59. Available from: https://doi.org/10.32508/ stdj.v20iK6.1171.

14. SCUD (Fujian) Electronics Co.,Ltd.. Sanyo Lithium Ion Baterry UR18650F-SCUD-3. [Online];Available from: Http://www.batteryonestop.com/baotongusa/products/liion/sanyo-ur18650f-26a.pdf.

15. J. Molenda. Li-ion batteries for electric vehicles. Annales Universitatis Mariae Curie Sklodowska Lulblin - Polonia. 2011;66:23-36. Available from: https://doi.org/10.2478/ v10063-011-0004-z.

16. Tung HD, Tong HY, Hung NT, Anh NTN. Development of emission factors and emission inventories for motorcycles and light duty vehicles in the urban region in Vietnam. Science of the Total Environment. 2011;409:2761-2767. PMID: 21549413. Available from: https://doi.org/10.1016/j.scitotenv. 2011.04.013.

17. Honda Vietnam. Operation and maintenance manual for Honda Lead 110cc. 2011;

18. Department of Domestic Market / Ministry of Industry and Trade. Petroleum consumption report for the first 6 months of 2018. Conference on propagating the development and use of bio-fuel, HCMC. 2018; 
19. Nam ND. Surveying the situation of environmental pollution caused by motorbike exhaust gas and proposing solutions.
Master graduated thesis. HCMUTE. 2018; 


\title{
Nghiên cứu tối ưu tính năng bộ nguồn pin Lithium-ion và chi phí vận hành cho xe gắn máy tích hợp truyền động lai
}

\author{
Nguyễn Văn Trạng ${ }^{1}$, Nguyễn Duy Tấn ${ }^{2, *}$, Phạm Tuấn Anh ${ }^{3}$
}

Use your smartphone to scan this QR code and download this article

\begin{abstract}
TÓM TẮT
Nghiên cứu này thực hiện trên xe máy lai xăng điện được cải tạo từ xe nền Honda Lead 110cc với bánh sau được dẫn động bằng động cơ đốt trong thông qua hệ thống truyển lực nguyên bản của xe, bánh trước được dẫn động trực tiếp bằng động cơ điện một chiểu không chổi than 48V 1000W. Nội dung chính của nghiên cứu là chế tạo, thử nghiệm bộ nguồn điện sử dụng pin Lithiumion thay thế cho bộ nguồn ắc quy axit - chì. Mô phỏng hoạt động, đánh giá tính năng động lực học đồng thời tính toán chi phí cải tạo và vận hành xe.

Nghiên cứu đã tính toán thiết kế, chế tạo một bộ nguồn pin Li-ion 48V - 33Ah với mạch BMS để lắp lên xe. Bộ pin có khối lượng 10.84 kg và thể tích 8.11 lít, giảm được $30 \mathrm{~kg}$ và 12.89 lít so với ắc quy axit - chì. Tuổi thọ của bộ pin lớn hơn 2,000 chu kỳ.

Ở chế độ chỉ hoạt động với mình động cơ điện, xe có thể di chuyển được quãng đường dài nhất là $78.77 \mathrm{~km}$ cho $\frac{1}{2}$ tải và $65.83 \mathrm{~km}$ cho trường hợp đầy tải. Vận tốc lớn nhất là $52.67 \mathrm{~km} / \mathrm{h}$ cho $\frac{1}{2}$ tải và $48.42 \mathrm{~km} / \mathrm{h}$ cho trường hợp đầy tải. Ở chế độ hybrid đến khi SOC $=50 \%$, xe đi được quãng đường $64.366 \mathrm{~km}$ cho $\frac{1}{2}$ tải và $54.477 \mathrm{~km}$ cho trường hợp đầy tải. Tiêu hao nhiên liệu tương ứng trong hai trường hợp là 2.162 và 2.425 lít/100km, giảm hơn 0.5 lít so với xe nền và 0.3 lít so với xe dùng bộ nguôn ắc quy axit - chì.

Chi phí cho xe đầu tư cho xe hybrid là 56 triệu đông còn chi phí khai thác là 1,106đ/km, trong khi xe nền là 40 triệu đồng và 1,352đ/km. Cứ mỗi km khai thác xe hybrid tiết kiệm được 246.88đ, sau khoảng 3,1 năm sẽ hòa vốn chi phí đầu tư. Nếu khai thác hết vòng đời xe khoảng $200,000 \mathrm{~km}$, xe hybrid tiết sẽ kiệm được khoảng 43 triệu đồng.

Từ khoá: Pin Lithium-ion, xe máy lai, xe hybrid, mạch quản lý pin
\end{abstract}

${ }^{1}$ Truờng Đại học Sui phạm Kỹ thuật Tp.HCM

${ }^{2}$ Trường Đại học Trân Đại Nghĩa

${ }^{3}$ Trường Đại học Nguyễn Tất Thành

Liên hệ

Nguyễn Duy Tấn, Trường Đại học Trần Đại Nghĩa

Email: duytan719@gmail.com

Lịch sử

- Ngày nhận: 23-9-2019

- Ngày chấp nhận: 31-12-2020

- Ngày đăng: 28-02-2021

DOI : 10.32508/stdjet.v3iSI2.600

\section{Check for updates}

\section{Bản quyền}

๑) ĐHQG Tp.HCM. Đây là bài báo công bố mở được phát hành theo các điều khoản của the Creative Commons Attribution 4.0

International license.

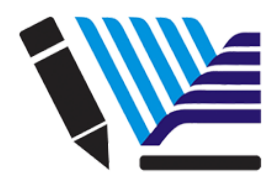

VNU-HCM Press
Trích dẫn bài báo này: Trạng $\mathrm{N} V$, Tấn $\mathrm{N} D$, Anh $\mathrm{P} T$. Nghiên cứu tối ưu tính năng bộ nguồn pin Lithium-ion và chi phí vận hành cho xe gắn máy tích hợp truyền động lai. Sci. Tech. Dev. J. - Eng. Tech.; 3(SI2):SI81-SI92. 